\title{
Adding Glucagon-Stimulated GH Testing to the Diagnostic Fast Increases the Detection of GH-Sufficient Children
}

\author{
Colin P. Hawkes ${ }^{a, c, d}$ Adda Grimberg ${ }^{a, b}$ Vivian E. Dzata ${ }^{a}$ Diva D. De Leon ${ }^{a, b}$ \\ ${ }^{a}$ Division of Endocrinology and Diabetes, The Children's Hospital of Philadelphia, and ${ }^{b}$ Department of Pediatrics, \\ Perelman School of Medicine, University of Pennsylvania, Philadelphia, Pa., USA; ${ }^{C}$ Department of Paediatrics and \\ Child Health, University College Cork, Cork, and ${ }^{\mathrm{d}}$ National Children's Research Centre, Dublin, Ireland
}

\section{Key Words}

Hypoglycemia · Growth hormone · Short stature - Glucagon · Testing · Stimulation

\begin{abstract}
Background/Aims: The evaluation of children with unexplained hypoglycemia may include a diagnostic fast. However, low growth hormone (GH) concentration during hypoglycemia is not specific to GH deficiency (GHD). The aim of this study was to determine if serial GH measurement following glucagon administration, in the setting of a diagnostic fast, would increase the number of children identified as not having GHD. Methods: We conducted a retrospective chart review of children who had serial GH measurements performed after glucagon administration at the end of a diagnostic fast. Glucagon was administered at the end of the fasting study, and GH was measured every $30 \mathrm{~min}$ for $210 \mathrm{~min}$. Results: Of the 29 children in this series, only $3(10 \%)$ had GH concentrations $>7 \mathrm{ng} / \mathrm{ml}$ at the end of the fast, which increased by 16 (55\%) after serial GH testing. The percentages of samples with $\mathrm{GH}$ concentrations $>7 \mathrm{ng} / \mathrm{ml}$ were: $10 \%$ at baseline, and 25, 39, 41, 41, 33, 43, and $0 \%$ every $30 \mathrm{~min}$ thereafter. Conclusion: Additional GH measurements after glucagon administration following a diagnostic fast can im-
\end{abstract}

prove the identification of children without GHD and thereby save them unnecessary $\mathrm{GH}$ stimulation testing and potential GH treatment.

(c) 2016 S. Karger AG, Basel

\section{Introduction}

Growth hormone (GH) plays an important role in the regulation of substrate use in the fasting state. Prolonged fasting results in an increase in frequency and amplitude of GH bursts [1] and GH secretion increases as blood glucose falls below $60 \mathrm{mg} / \mathrm{dl}[2,3]$. GH promotes lipolysis [4] and reduces utilization of protein [5-7] and glucose [8]. It also causes insulin resistance through direct downstream effects on insulin signaling $[9,10]$, as well as indirectly by increasing nonesterified free fatty acid concentrations [4]. Consequently, hypoglycemia can be a presenting feature of GH deficiency (GHD) [11-13]. This is generally more problematic in younger infants $[14,15]$, although older children with GHD may have impaired fasting tolerance [13].

Severe hypoglycemia in childhood can be associated with adverse neurocognitive outcomes [16-18], and the identification and treatment of the cause of hypoglycemia

\section{KARGER}

E-Mail karger@karger.com

www.karger.com/hrp (c) 2016 S. Karger AG, Basel

$1663-2818 / 16 / 0854-0265 \$ 39.50 / 0$
Dr. Colin P. Hawkes

Division of Endocrinology and Diabetes, The Children's Hospital of Philadelphia 34th Street and Civic Center Blvd

Philadelphia, PA 19104 (USA)

E-Mail hawkesc@email.chop.edu 
disorders is critical in minimizing this risk. In addition to GHD, the differential diagnosis for hypoglycemia in childhood includes disorders of intermediary fuel metabolism, excess or inappropriate insulin secretion, and adrenal insufficiency. The standard approach to determining the etiology of hypoglycemia includes the measurement of the fuel and hormonal responses in the 'critical' lab sample drawn during hypoglycemia $[19,20]$. Where possible, these serum markers are measured during opportunistic hypoglycemia, but a structured diagnostic fasting study may be required. Although GH increases as blood glucose concentration falls, low GH concentrations during hypoglycemia are commonly seen at the time of drawing the critical sample even in the absence of GHD [21-24].

The evaluation of GHD as a potential cause of hypoglycemia is complicated by the lack of a reliable and specific gold standard test for this condition. GH stimulation tests (GHSTs) are recommended to confirm GHD in children with clinical suspicion of GHD $[25,26]$. Factors including the assay used and individual pharmacokinetics also influence the serum GH concentrations measured in these tests [27]. A large proportion of infants [28] and older children [29-31] will not have GH concentrations above arbitrary GH thresholds using these tests. Consequently, the misdiagnosis of children with GHD as the etiology of their hypoglycemia is possible and may result in the initiation of an incorrect treatment plan.

Glucagon is used clinically to assess the inappropriate availability of glucose stores (glycogen) during hypoglycemia. In a child with hypoglycemia, an inappropriate rise in glucose concentration following glucagon administration may be consistent with hyperinsulinism $[19,32]$ or hypopituitarism (in the newborn period) [33]. Glucagon is also a GH secretagogue, and the serial measurement of GH concentration following glucagon administration is used as one of the GHSTs of GH sufficiency in children with suspected GHD [34]. When intramuscular glucagon is used to assess GH secretion, peak GH concentrations are generally seen between 90 and 120 min following administration $[28,35]$. Although glucagon is administered at the end of many fasting studies to evaluate glycogen stores, the routine serial measurement of GH following this glucagon administration is not generally performed.

The aim of this study was to determine if the serial measurement of GH concentration following glucagon administration, in the setting of a diagnostic evaluation of a child with unexplained hypoglycemia, would increase the number of children identified as not having GHD.

\section{Methods}

Given the poor specificity of GH measurement during hypoglycemia for GHD [22], a clinical protocol for incorporating serial GH measurement after glucagon administration during hypoglycemia was developed. The only additional intervention in this clinical protocol was the serial measurement of GH following glucagon administration in children with unexplained hypoglycemia and clinical suspicion of GHD. This protocol was implemented in 2012 for patients in whom GHD was considered clinically as a likely etiology of their hypoglycemia, and medical records were retrospectively reviewed in March 2015. This study was approved by the Institutional Review Board at The Children's Hospital of Philadelphia.

\section{Protocol}

At The Children's Hospital of Philadelphia, the diagnostic evaluation of hypoglycemia includes a standard diagnostic fasting study. The maximum fasting time is age dependent. Children aged $<1$ month are fasted for up to $18 \mathrm{~h}$, those between 1 and 12 months for up to $24 \mathrm{~h}$, and children over 1 year for up to $36 \mathrm{~h}$. The monitoring protocol depends on the clinical scenario, but generally includes blood glucose monitoring during the fast using a bedside glucose meter (Nova StatStrip point-of-care glucose monitor; Nova Biomedical Corporation, Waltham, Mass., USA) every 3 h until blood glucose is $<70 \mathrm{mg} / \mathrm{dl}$, hourly until it is $<60 \mathrm{mg} / \mathrm{dl}$, and every $30 \mathrm{~min}$ until it is $<50 \mathrm{mg} / \mathrm{dl}$. $\beta$-Hydroxybutyrate is also measured at the bedside every 3 h using a handheld meter (PrecisionXtra; Abbott Laboratories). The study is ended when a confirmatory glucose of $<50$ $\mathrm{mg} / \mathrm{dl}$ is recorded, if $\beta$-hydroxybutyrate concentration exceeds 2.5 $\mathrm{mmol} / \mathrm{l}$, or if the maximum predetermined fasting time is reached.

A full critical blood draw is taken at the end of the fast. This includes the measurement of glucose, free fatty acids, $\beta$-hydroxybutyrate, insulin, ammonia, lactate, basal metabolic profile, acylcarnitine, C-peptide, carnitine, insulin-like growth factorbinding protein (IGFBP)-1, cortisol, and GH. At the end of the diagnostic fast, glucagon is administered intravenously at a dose of $1 \mathrm{mg}$ for all patients, and glucose is measured every $10 \mathrm{~min}$ by bedside glucose meter. Dextrose is administered if blood glucose does not rise by at least $20 \mathrm{mg} / \mathrm{dl}$ within $20 \mathrm{~min}$. If, however, glucose concentration rises by at least $20 \mathrm{mg} / \mathrm{dl}$, then blood glucose checks are continued for a further $20 \mathrm{~min}$ before the fast is ended. If at any point during the glucagon test the child is unwell, dextrose is administered. The administration of dextrose at the end of the fast consists of a $2-\mathrm{ml} / \mathrm{kg}$ bolus of $10 \%$ dextrose, and the child is provided a meal containing $40 \mathrm{~g}$ of carbohydrates.

In addition to this standard protocol, additional GH concentrations were measured in patients in whom there was clinical suspicion of GHD. GH concentrations were measured at 30, 60, 90, 120, 150,180 , and 120 min following glucagon administration (fig. 1). Where there were clinical limitations to the blood volume that could be drawn, the 90 - and 120 -min specimens were prioritized.

\section{Laboratory Measurement}

GH was measured by a solid-phase, two-site chemiluminescent immunometric assay (Immulite 2000; Siemens, Berlin, Germany), plasma glucose by an oxidase colorimetric reaction (Vitros 5600; Ortho Clinical Diagnostics, Raritan, N.J., USA) and betahydroxybutyrate by a D-3 hydroxybutyrate dehydrogenase colorimetric reaction (Vitros 5600; Ortho Clinical Diagnostics). IGF-I was measured by radioimmunoassay after acid ethanol extraction (Esoter- 
Fig. 1. Protocol for additional GH measurements after glucagon administration, in the context of a diagnostic fasting study. $\mathrm{BOHB}=\beta$-Hydroxybutyrate.

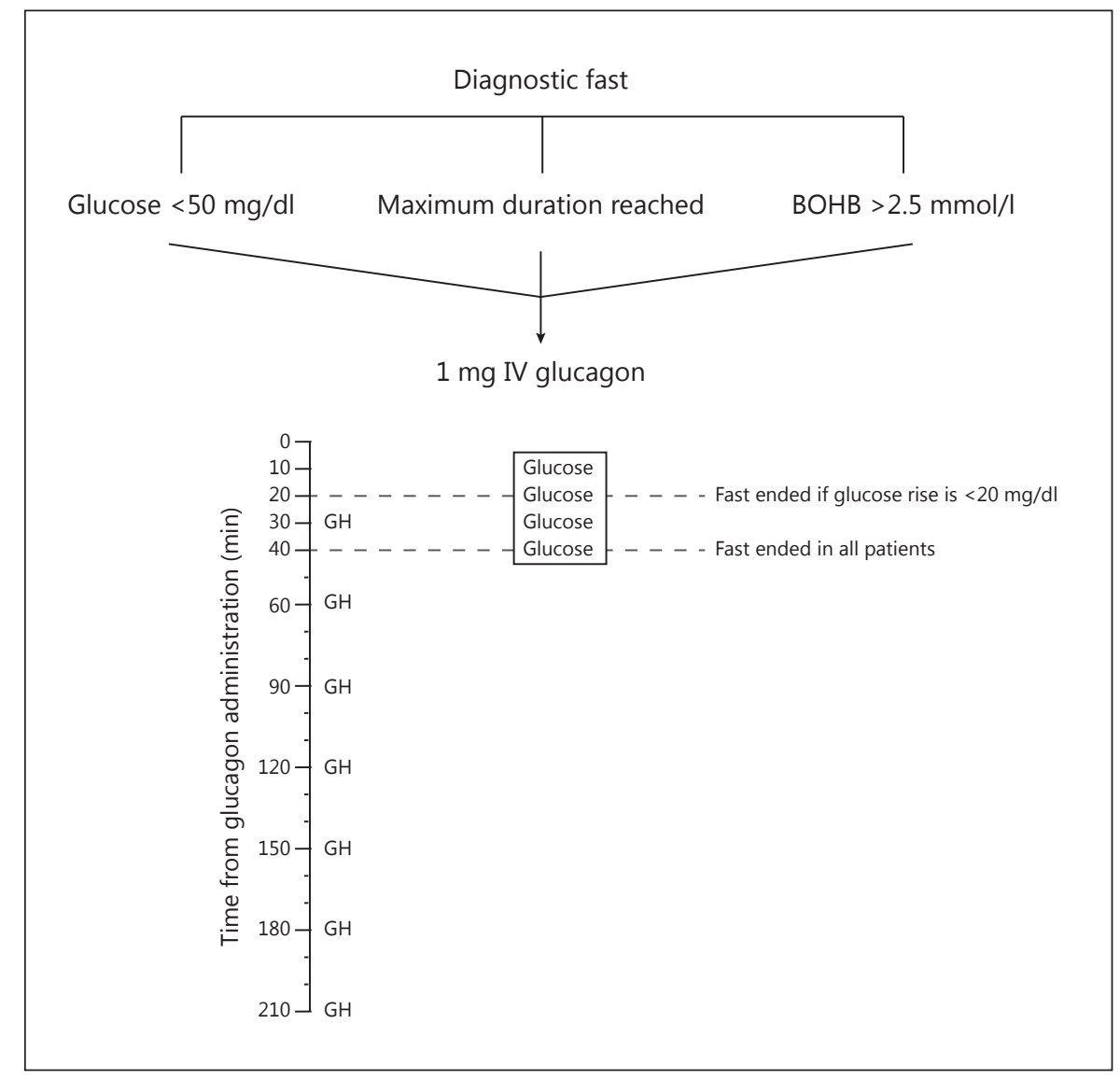

ix Laboratories, Austin, Tex., USA) and IGFBP-3 was measured by radioimmunoassay (Esoterix Laboratories). Where relevant, assay-specific Z-scores for age and gender were reported.

\section{Statistical Analysis}

The threshold GH concentration considered to represent GH sufficiency varies between centers and generally ranges from 5 to $10 \mathrm{ng} / \mathrm{ml}[36,37]$. In this study, we use $7 \mathrm{ng} / \mathrm{ml}$ as the threshold for $\mathrm{GH}$ sufficiency. We also describe overall data if thresholds of 5 or $10 \mathrm{ng} / \mathrm{ml}$ were used.

Height and weight Z-scores at the time of the stimulation test were generated using the World Health Organization standards [38]. Unless otherwise stated, continuous variables were presented as the median (interquartile range). All data analyses were performed using SPSS 22.0 (IBM, N.Y., USA). Figures were generated using Prism 5.0 (GraphPad Software Inc., Calif., USA) and Adobe Illustrator 16.0 (Adobe Systems Inc., Calif., USA).

\section{Results}

Between July 2013 and March 2015, 29 patients with unexplained hypoglycemia and suspected GHD (largely due to coexisting short stature) had serial GH measure- ment following diagnostic fast and glucagon administration. The median (interquartile range) height $\mathrm{Z}$-score was $-2.3(-3.3,-1)$. Of these patients, 6 had a final diagnosis of GHD and were treated with GH. The remaining patients had a diagnosis of hyperinsulinism $(n=9)$, ketotic hypoglycemia $(\mathrm{n}=13)$, or mitochondrial disorder $(\mathrm{n}=1)$. Out of all children included in this study, 4 (14\%), 3 (10\%), and 1 (3\%) had GH concentrations above thresholds of 5, 7, and $10 \mathrm{ng} / \mathrm{ml}$, respectively, at the end of the diagnostic fast. The additional GH measurement after glucagon administration identified 24 (86\%), 19 (66\%), and $15(52 \%)$ children with GH concentrations exceeding these thresholds. The demographics of the patients included in this study are shown in table 1 .

Of the 29 patients in this series, only 3 (10\%) had GH concentrations $>7 \mathrm{ng} / \mathrm{ml}$ at the end of the fasting study, and all 3 of these children also had GH measurements above this threshold again on serial testing. The percentage of samples with $\mathrm{GH}$ concentrations above 5, 7, and 10 $\mathrm{ng} / \mathrm{ml}$ at each time point is shown in figure 2 . These data suggest that samples at 60,90 , and 120 min after glucagon 


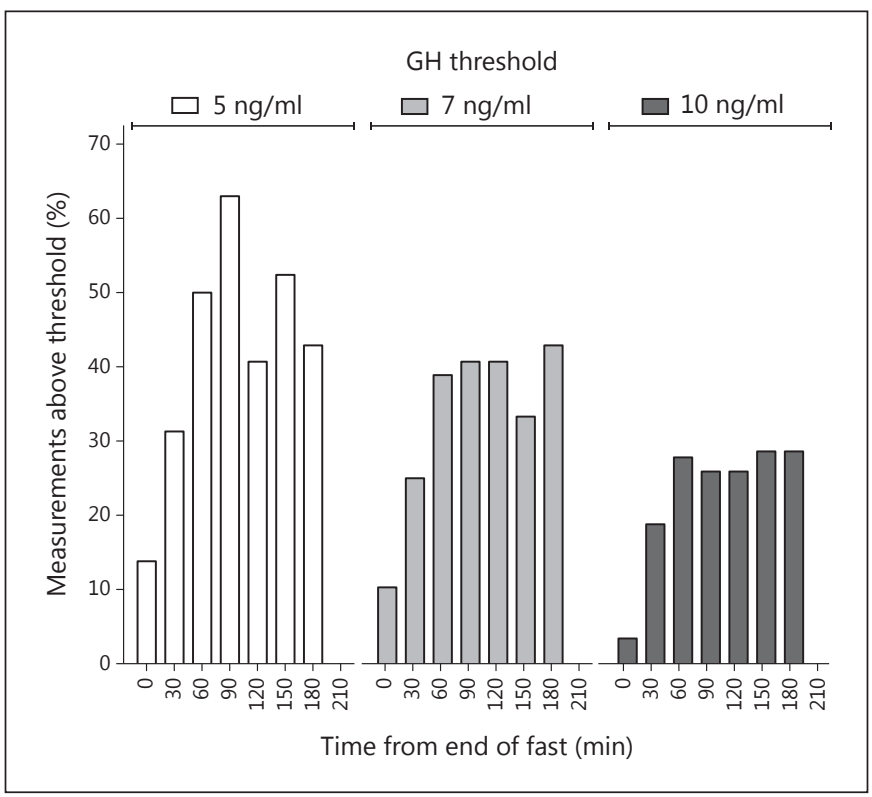

Fig. 2. The percentage of children with $\mathrm{GH}$ concentrations greater than or equal to thresholds of 5,7 , or $10 \mathrm{ng} / \mathrm{ml}$ at the time of glucagon administration at the end of the diagnostic fasting study $(\mathrm{n}=29)$, or $30(\mathrm{n}=16), 60(\mathrm{n}=18), 90(\mathrm{n}=27), 120(\mathrm{n}=27), 150$ $(\mathrm{n}=21), 180(\mathrm{n}=7)$ or $210 \mathrm{~min}(\mathrm{n}=3)$ later.

administration should be prioritized where frequent sampling is not possible.

Of the $26(90 \%)$ patients with $\mathrm{GH}$ concentrations $<7$ $\mathrm{ng} / \mathrm{ml}$ during hypoglycemia, 10 (34\%) also had peak GH concentrations below this threshold on serial measurement after glucagon administration. Of these 10 children without $\mathrm{GH}$ concentrations $>7 \mathrm{ng} / \mathrm{ml}, 9$ underwent additional GH stimulation testing using arginine and clonidine. Six were diagnosed with GHD and treated with GH. Two children did not have peak GH concentrations $>7$ $\mathrm{ng} / \mathrm{ml}$ following arginine and clonidine stimulation testing, but their clinical picture was considered to be more consistent with hyperinsulinism than GHD, and they were not treated with GH. Both of these children were treated with diazoxide, with a good clinical response.

Characteristics and diagnostic evaluation of the $10 \mathrm{pa}-$ tients with suboptimal peak GH concentrations are shown in table 2. Additional diagnostic information on cases 7 and 8 from this series is provided, as the diagnosis may be unclear from the data presented in this table. Although case 7 had normal growth factor concentrations, it should be noted that IGF-I concentrations are sensitive to nutrition [39] and, in infancy, do not reliably identify infants with GHD due to the wide range of normal con-
Table 1. Demographic data, diagnoses, critical sample measurements, and serial GH concentrations following glucagon administration

\begin{tabular}{|c|c|}
\hline Males, n (\%) & $16(55)$ \\
\hline Age, years & $1.8(0.7,3.4)$ \\
\hline Height, Z-score & $-2.3(-3.3,-1)$ \\
\hline Weight, Z-score & $-1.2(-2.3,-1)$ \\
\hline Duration of fast, $\mathrm{h}$ & $15(9.8,20)$ \\
\hline \multicolumn{2}{|l|}{ Final diagnosis, $\mathrm{n}(\%)$} \\
\hline Hyperinsulinism & $9(31)$ \\
\hline Ketotic hypoglycemia & $13(45)$ \\
\hline Mitochondrial disorder & $1(4)$ \\
\hline GHD & $6(21)$ \\
\hline \multicolumn{2}{|l|}{ Lab tests at the end of the fast } \\
\hline Glucose, mg/dl & $45(42,51.5)$ \\
\hline Cortisol, $\mu \mathrm{g} / \mathrm{dl}$ & $16(10.3,20.5)$ \\
\hline$\beta$-Hydroxybutyrate, mmol/l & $2.4(1.5,2.75)$ \\
\hline \multicolumn{2}{|l|}{$\mathrm{GH}$ measurements ${ }^{1}, \mathrm{ng} / \mathrm{ml}$} \\
\hline Baseline $(\mathrm{n}=29)$ & $2.6(1,3.5)$ \\
\hline $30 \min (n=16)$ & $2.5(1.6,8.2)$ \\
\hline $60 \min (n=18)$ & $4.9(2.4,10.7)$ \\
\hline $90 \min (n=27)$ & $5.6(4.2,12.9)$ \\
\hline $120 \min (n=27)$ & $4.4(2.5,10.2)$ \\
\hline $150 \min (\mathrm{n}=21)$ & $5.1(2.2,11)$ \\
\hline $180 \min (n=7)$ & $3.2(1.2,11.6)$ \\
\hline $210 \min (n=3)$ & $3.6(2,4.9)$ \\
\hline \multicolumn{2}{|l|}{ Subjects who exceeded threshold on testing } \\
\hline $\mathrm{GH}>5 \mathrm{ng} / \mathrm{ml}$ at baseline & $4(14)$ \\
\hline $\mathrm{GH}>5 \mathrm{ng} / \mathrm{ml}$ after serial measurements & $25(86)$ \\
\hline $\mathrm{GH}>7 \mathrm{ng} / \mathrm{ml}$ at baseline & $3(10)$ \\
\hline $\mathrm{GH}>7 \mathrm{ng} / \mathrm{ml}$ after serial measurements & $19(66)$ \\
\hline $\mathrm{GH}>10 \mathrm{ng} / \mathrm{ml}$ at baseline & $1(3)$ \\
\hline $\mathrm{GH}>10 \mathrm{ng} / \mathrm{ml}$ after serial measurements & $15(52)$ \\
\hline
\end{tabular}

Data are presented as the median (interquartile range), unless otherwise indicated. ${ }^{1}$ Note that $\mathrm{n}$ represents the number of data points available for $\mathrm{GH}$ measurement at each time point.

centrations [40]. This infant also had low random GH measurements on days $3(1.11 \mathrm{ng} / \mathrm{ml})$ and $14(0.334 \mathrm{ng} /$ $\mathrm{ml}$ ) of life, also supporting the diagnosis of GHD [41]. Case 8 had a diagnosis of focal hyperinsulinism based on a known pathogenic $A B C C 8$ mutation and previous fasting evaluations consistent with hyperinsulinism. The diagnostic evaluation presented in table 2 was from an evaluation after the focal lesion had been removed and the hyperinsulinism had resolved. Although his peak GH concentration did not exceed the threshold of $7 \mathrm{ng} / \mathrm{ml}$, his linear growth pattern was not consistent with GHD, and a decision was made to observe his growth rather than initiate treatment. 
Table 2. Details of the 10 children without peak GH concentrations $>7 \mathrm{ng} / \mathrm{ml}$ after the fasting study and glucagon administration

\begin{tabular}{|c|c|c|c|c|c|c|c|c|c|c|}
\hline Patient: & 1 & 2 & 3 & 4 & 5 & 6 & 7 & 8 & 9 & 10 \\
\hline Height, Z-score & -1.2 & -0.81 & -2.33 & -2.2 & -4.1 & -0.75 & -0.02 & -2.47 & -3.6 & -0.94 \\
\hline MRI brain and pituitary & normal & NP & NP & normal & $\mathrm{NP}$ & $\mathrm{NP}$ & $\begin{array}{l}\text { abnormal } \\
\text { corpus } \\
\text { callosum }\end{array}$ & $\mathrm{NP}$ & $\begin{array}{l}\text { ectopic } \\
\text { neurohypophysis }\end{array}$ & normal \\
\hline \multicolumn{11}{|l|}{ Critical Sample } \\
\hline Glucose, mg/dl & 41 & 45 & 49 & 47 & 43 & 51 & 46 & 53 & 45 & 52 \\
\hline$\beta$-Hydroxybutyrate, $\mathrm{mmol} / \mathrm{l}$ & 2.9 & 1.2 & 2.2 & 2.9 & 2.5 & 4 & 0.1 & 2.5 & 0.8 & 2.3 \\
\hline $\mathrm{GH}, \mathrm{ng} / \mathrm{ml}$ & 3.6 & 1 & 1.1 & 2.4 & 3.5 & 3.5 & 0.8 & 2.4 & 0.1 & 3.2 \\
\hline Cortisol, $\mu \mathrm{g} / \mathrm{dl}$ & 20.8 & 14.4 & 28.9 & 9.3 & 14.3 & 40.7 & 14.9 & 16.3 & 6 & 20.6 \\
\hline Peak GH after glucagon, ng/ml & 5.4 & 5.2 & 5.5 & 5.1 & 4.7 & 5.7 & 4.3 & 4.7 & 0.3 & 6.6 \\
\hline $\begin{array}{l}\text { Peak GH on repeat GH } \\
\text { stimulation test, } \mathrm{ng} / \mathrm{ml}\end{array}$ & 7.1 & 4.6 & & 6.5 & 3.7 & 8.2 & 1.9 & 6.2 & 0.4 & 1.5 \\
\hline Diagnosis & $\mathrm{GHD}^{1}$ & $\mathrm{HI}$ & $\mathrm{KH}$ & GHD & GHD & $\mathrm{KH}$ & GHD & $\begin{array}{l}\text { resolved } \\
\text { focal HI }\end{array}$ & GHD, AI & GHD \\
\hline
\end{tabular}

$\mathrm{NA}=$ No data available; $\mathrm{NP}=$ test not performed; $\mathrm{HI}=$ diazoxide-responsive hyperinsulinism; $\mathrm{KH}=$ ketotic hypoglycemia; $\mathrm{AI}=$ adrenal insufficiency. ${ }^{1}$ Additional clinical data supporting the diagnosis of GHD: height velocity $3 \mathrm{~cm} /$ year, bone age delayed by 2 years $(-2.3 \mathrm{SD}$ from the mean), improved growth, and no further hypoglycemia following GH treatment.

\section{Discussion}

We have shown that the serial measurement of GH following the administration of glucagon in the context of a fasting study can be a useful adjunct in children suspected of having GHD. GH measurement during hypoglycemia has poor specificity for GHD and, by adding serial GH measurements following glucagon administration, the number of children identified with peak GH concentrations above the arbitrary threshold of $7 \mathrm{ng} / \mathrm{ml}$ increased by $16(55 \%)$. This resulted in a more focused evaluation of GH secretion in a smaller number of children than would otherwise have been performed.

The poor specificity of GH measurement during hypoglycemia has previously been described. In a study including 84 children evaluated for unexplained hypoglycemia, only $30 \%$ had peak GH concentrations $>7.5 \mathrm{ng} / \mathrm{ml}$ [22]. In our study, there was a lower number $(10 \%)$ of children with peak GH concentration $>7 \mathrm{ng} / \mathrm{ml}$ during hypoglycemia. However, additional GH measurements were only performed in children for whom there was clinical suspicion that GHD was the etiology of their hypoglycemia, and this selection bias may have contributed to the discrepancy in results between our study and previously reported data.
One limitation to adapting our clinical protocol was the blood volume required for additional GH measurements in small infants with unexplained hypoglycemia. Serial glucose measurement during the diagnostic fast, in addition to the critical sample, can limit the blood volume that can be extracted for further tests. Previous studies suggest that the peak $\mathrm{GH}$ concentration following glucagon administration (glucagon stimulation test for $\mathrm{GH}$ reserve) generally occur after 90 and $120 \mathrm{~min}[28,34,42$, 43]. Where necessary, GH samples were prioritized at 90 and $120 \mathrm{~min}$ in this study, and we have shown that these are the most useful measurements in this context to identify GH-sufficient children (fig. 2). Although not evaluated in this study, we note that cortisol responses to glucagon administration occur later, at 150 and $180 \mathrm{~min}$ [35, 43], and this should be considered if future studies of this test are adapted to evaluate cortisol response to glucagon in this context.

The mechanism of glucagon-induced GH secretion is not clear. Fluctuations in blood glucose following glucagon administration may contribute to $\mathrm{GH}$ secretion, although recent studies suggest that this may not be necessary $[34,44]$. Glucagon administration increases noradrenaline secretion, [45] which may play a role in 
stimulating $\mathrm{GH}$ secretion, but $\alpha$-adrenergic blockade does not prevent glucagon-induced GH secretion [46]. Although fasting increases $\mathrm{GH}$ secretion $[47,48]$, it was not clear if allowing the patient to feed while measuring $\mathrm{GH}$ concentrations after glucagon secretion would affect the ability of the test to identify children with GH concentrations above the stimulation threshold. A large proportion (17/27) of children in this study had an appropriate stimulated GH response to glucagon despite having been allowed to feed.

We do not know if the serial GH response noted in this study would have been seen if glucagon was not provided. Hypoglycemia is a strong stimulus for GH secretion in the absence of additional pharmacological stimuli, and this is utilized in the commonly used insulin tolerance test of GH secretion. However, the GH response to spontaneous hypoglycemia in children is blunted in comparison to insulin tolerance testing [21]. This makes the GH concentrations seen in this study more likely to be secondary to glucagon administration rather than to hypoglycemia. We also acknowledge that an intramuscular injection of glucagon may result in higher detectable concentrations of GH relative to IV glucagon [49], possibly as a result of an additional painful stimulus [50]. As intramuscular or subcutaneous glucagon are more potent stimuli of $\mathrm{GH}$ secretion $[49,51,52]$, it is possible that modifying the protocol to utilize these routes of administration would further improve the specificity for GHD. However, this route of glucagon administration is not routinely used in evaluating the glycemic response to hypoglycemia in our practice. Thus, we are unable to compare different routes of glucagon administration in this study.

It is important to note that many normal children will be characterized as having GHD on the GHST alone [2931 ], and these results should be interpreted in the clinical context. Depending on the GH stimulus and GH concentration threshold used, the proportion of normal children who do not reach the 'sufficient' threshold can be as high as half [29]. In this study, only children suspected of hav- ing GHD at the time of the diagnostic fasting study underwent this additional serial GH measurement. Given the poor reliability of the GHST, we do not routinely perform the GHST in children with peak GH concentrations $<7 \mathrm{ng} / \mathrm{ml}$ where the laboratory tests performed during hypoglycemia indicate that alternative diagnoses are more likely. In addition, GHD is not always diagnosed if peak GH concentrations on arginine and clonidine stimulation testing do not exceed $7 \mathrm{ng} / \mathrm{ml}$ in these patients. This clinical judgement and lack of robust diagnostic tools may result in children with diagnoses such as ketotic hypoglycemia being misdiagnosed as GHD.

In conclusion, we have shown that additional $\mathrm{GH}$ measurements after glucagon administration following a diagnostic fast can improve the identification of children with stimulated GH concentrations above stimulation test thresholds. This test can be performed in addition to the diagnostic fasting study and does not require prolongation of the fast. We also recommend that children with insufficient responses to glucagon in this setting should further have GHD confirmed by standard GHSTs if there is clinical suspicion of GHD.

\section{Acknowledgements}

We wish to acknowledge Diego Campos for his efforts of extracting the electronic health records for this project and Stephanie Givler for her assistance with the protocol. Dr. Hawkes is supported by a $\mathrm{PhD}$ grant by the National Children's Research Centre, Dublin, Ireland, Dr. Grimberg is supported by grant 1R01 HD57037 from the Eunice Kennedy Shriver National Institute of Child Health and Human Development, and Dr. De Leon is supported by grant 5R01DK098517 from the National Institute of Diabetes and Digestive and Kidney Diseases.

\section{Disclosure Statement}

C.P.H., V.E.D., and D.D.D.L. have no financial relationships relevant to this article to disclose. A.G. serves on the Steering Committee of the Pfizer International Growth Study Database.

References

Hartman ML, Veldhuis JD, Johnson ML, Lee MM, Alberti KG, Samojlik E, Thorner MO: Augmented growth hormone (GH) secretory burst frequency and amplitude mediate enhanced GH secretion during a two-day fast in normal men. J Clin Endocrinol Metab 1992; 74:757-765.

-2 Amiel SA, Simonson DC, Sherwin RS, Lauritano AA, Tamborlane WV: Exaggerated epi- nephrine responses to hypoglycemia in normal and insulin-dependent diabetic children. J Pediatr 1987;110:832-837.

3 Sperling MA, DeLamater PV, Phelps D, Fiser $\mathrm{RH}, \mathrm{Oh}$ W, Fisher DA: Spontaneous and amino acid-stimulated glucagon secretion in the immediate postnatal period. Relation to glucose and insulin. J Clin Invest 1974;53:11591166. 
4 Copeland KC, Nair KS: Acute growth hormone effects on amino acid and lipid metabolism. J Clin Endocrinol Metab 1994;78:10401047.

5 Moller N, Vendelbo MH, Kampmann U, Christensen B, Madsen M, Norrelund H, Jorgensen JO: Growth hormone and protein metabolism. Clin Nutr 2009;28:597-603.

6 Norrelund H, Nair KS, Jorgensen JO, Christiansen JS, Moller N: The protein-retaining effects of growth hormone during fasting involve inhibition of muscle-protein breakdown. Diabetes 2001;50:96-104.

7 Haymond MW, Karl I, Weldon VV, Pagliara AS: The role of growth hormone and cortisone on glucose and gluconeogenic substrate regulation in fasted hypopituitary children. J Clin Endocrinol Metab 1976;42:846-856.

8 Moller N, Jorgensen JO: Effects of growth hormone on glucose, lipid, and protein metabolism in human subjects. Endocr Rev 2009;30:152-177.

-9 Takano A, Haruta T, Iwata M, Usui I, Uno T, Kawahara J, Ueno E, Sasaoka T, Kobayashi M: Growth hormone induces cellular insulin resistance by uncoupling phosphatidylinositol 3-kinase and its downstream signals in 3T3L1 adipocytes. Diabetes 2001;50:1891-1900.

-10 Campbell PJ, Bolli GB, Cryer PE, Gerich JE: Pathogenesis of the dawn phenomenon in patients with insulin-dependent diabetes mellitus. Accelerated glucose production and impaired glucose utilization due to nocturnal surges in growth hormone secretion. $\mathrm{N}$ Engl J Med 1985;312:1473-1479.

11 Wolfsdorf JI, Sadeghi-Nejad A, Senior B: Hypoketonemia and age-related fasting hypoglycemia in growth hormone deficiency. Metabolism 1983;32:457-462.

$\$ 12$ Bell JJ, August GP, Blethen SL, Baptista J: Neonatal hypoglycemia in a growth hormone registry: incidence and pathogenesis. J Pediatr Endocrinol Metab 2004;17:629-635.

13 Jaquet D, Touati G, Rigal O, Czernichow P: Exploration of glucose homeostasis during fasting in growth hormone-deficient children. Acta Paediatr 1998;87:505-510.

14 Ogilvy-Stuart AL: Growth hormone deficiency (GHD) from birth to 2 years of age: diagnostic specifics of GHD during the early phase of life. Horm Res 2003;60:2-9.

15 Herber SM, Milner RD: Growth hormone deficiency presenting under age 2 years. Arch Dis Child 1984;59:557-560.

-16 Meissner T, Wendel U, Burgard P, Schaetzle S, Mayatepek E: Long-term follow-up of 114 patients with congenital hyperinsulinism. Eur J Endocrinol 2003;149:43-51.

17 Menni F, de Lonlay P, Sevin C, Touati G, Peigne C, Barbier V, Nihoul-Fekete C, Saudubray JM, Robert JJ: Neurologic outcomes of 90 neonates and infants with persistent hyperinsulinemic hypoglycemia. Pediatrics 2001;107:476-479.
18 Kaiser JR, Bai S, Gibson N, Holland G, Lin TM, Swearingen CJ, Mehl JK, ElHassan NO: Association between transient newborn hypoglycemia and fourth-grade achievement test proficiency: a population-based study. JAMA Pediatr 2015;169:913-921.

19 Palladino AA, Bennett MJ, Stanley CA: Hyperinsulinism in infancy and childhood: when an insulin level is not always enough. Clin Chem 2008;54:256-263.

20 Katz LE, Satin-Smith MS, Collett-Solberg P, Baker L, Stanley CA, Cohen P: Dual regulation of insulin-like growth factor binding protein-1 levels by insulin and cortisol during fasting. J Clin Endocrinol Metab 1998;83: 4426-4430.

21 Hussain K, Hindmarsh P, Aynsley-Green A: Spontaneous hypoglycemia in childhood is accompanied by paradoxically low serum growth hormone and appropriate cortisol counterregulatory hormonal responses. J Clin Endocrinol Metab 2003;88:3715-3723.

22 Kelly A, Tang R, Becker S, Stanley CA: Poor specificity of low growth hormone and cortisol levels during fasting hypoglycemia for the diagnoses of growth hormone deficiency and adrenal insufficiency. Pediatrics 2008; 122:e522-e528.

23 Morris AA, Thekekara A, Wilks Z, Clayton PT, Leonard JV, Aynsley-Green A: Evaluation of fasts for investigating hypoglycaemia or suspected metabolic disease. Arch Dis Child 1996;75:115-119.

24 Crofton PM, Midgley PC: Cortisol and growth hormone responses to spontaneous hypoglycaemia in infants and children. Arch Dis Child 2004;89:472-478.

25 Growth Hormone Research Society: Consensus guidelines for the diagnosis and treatment of growth hormone (GH) deficiency in childhood and adolescence: summary statement of the GH research society. GH Research Society. J Clin Endocrinol Metab 2000;85:39903993.

26 Wilson TA, Rose SR, Cohen P, Rogol AD, Backeljauw P, Brown R, Hardin DS, Kemp SF, Lawson M, Radovick S, Rosenthal SM, Silverman L, Speiser P, Lawson Wilkins Pediatric Endocrinology Society Drug and Therapeutics Committee: Update of guidelines for the use of growth hormone in children: the Lawson Wilkins Pediatric Endocrinology Society Drug and Therapeutics Committee. J Pediatr 2003;143:415-421.

27 Levin PA, Chalew SA, Martin L, Kowarski AA: Comparison of assays for growth hormone using monoclonal or polyclonal antibodies for diagnosis of growth disorders. J Lab Clin Med 1987;109:85-88.

28 Chanoine JP, Rebuffat E, Kahn A, Bergmann P, Van Vliet G: Glucose, growth hormone, cortisol, and insulin responses to glucagon injection in normal infants, aged 0.5-12 months. J Clin Endocrinol Metab 1995;80: 3032-3035.
29 Ghigo E, Bellone J, Aimaretti G, Bellone S, Loche S, Cappa M, Bartolotta E, Dammacco F, Camanni F: Reliability of provocative tests to assess growth hormone secretory status. Study in 472 normally growing children. J Clin Endocrinol Metab 1996;81:3323-3327.

30 Marin G, Domene HM, Barnes KM, Blackwell BJ, Cassorla FG, Cutler GB Jr: The effects of estrogen priming and puberty on the growth hormone response to standardized treadmill exercise and arginine-insulin in normal girls and boys. J Clin Endocrinol Metab 1994;79: 537-541.

31 Zadik Z, Chalew SA, Kowarski A: Assessment of growth hormone secretion in normal stature children using 24-hour integrated concentration of GH and pharmacological stimulation. J Clin Endocrinol Metab 1990;71:932936.

32 Finegold DN, Stanley CA, Baker L: Glycemic response to glucagon during fasting hypoglycemia: an aid in the diagnosis of hyperinsulinism. J Pediatr 1980;96:257-259.

33 Lovinger RD, Kaplan SL, Grumbach MM: Congenital hypopituitarism associated with neonatal hypoglycemia and microphallus: four cases secondary to hypothalamic hormone deficiencies. J Pediatr 1975;87:11711181.

34 Johnstone HC, Cheetham TD: GH and cortisol response to glucagon administration in short children. Horm Res 2004;62:27-32.

- 35 Bottner A, Kratzsch J, Liebermann S, Keller A, Pfaffle RW, Kiess W, Keller E: Comparison of adrenal function tests in children - the glucagon stimulation test allows the simultaneous assessment of adrenal function and growth hormone response in children. J Pediatr Endocrinol Metab 2005;18:433-442.

-36 Evans C, Gregory JW, All Wales Clinical Biochemistry Audit Group: The investigation of short stature: a survey of practice in Wales and suggested practical guidelines. J Clin Pathol 2004;57:126-130.

37 Sizonenko PC, Clayton PE, Cohen P, Hintz RL, Tanaka T, Laron Z: Diagnosis and management of growth hormone deficiency in childhood and adolescence. Part 1: diagnosis of growth hormone deficiency. Growth Horm IGF Res 2001;11:137-165.

38 WHO Multicentre Growth Reference Study Group: WHO child growth standards based on length/height, weight and age. Acta Paediatr Suppl 2006;450:76-85.

39 Hawkes CP, Grimberg A: Insulin-like growth factor-I is a marker for the nutritional state. Pediatr Endocrinol Rev 2015;13:465-477.

40 Hawkes CP, Grimberg A: Measuring growth hormone and insulin-like growth factor-I in infants: what is normal? Pediatr Endocrinol Rev 2013;11:126-146. 
41 Binder G, Hettmann S, Weber K, Kohlmüller D, Schweizer R: Analysis of the GH content within archived dried blood spots of newborn screening cards from children diagnosed with growth hormone deficiency after the neonatal period. Growth Horm IGF Res 2011;21:314317.

42 Lim SH, Vasanwala R, Lek N, Yap F: Quantifying the risk of hypoglycaemia in children undergoing the glucagon stimulation test. Clin Endocrinol (Oxf) 2011;75:489-494

43 Strich D, Terespolsky N, Gillis D: Glucagon stimulation test for childhood growth hormone deficiency: timing of the peak is important. J Pediatr 2009;154:415-419.

-44 Giuffrida FM, Berger K, Monte L, Oliveira $\mathrm{CH}$, Hoff AO, Maciel RM, Vieira JG: Relationship between $\mathrm{GH}$ response and glycemic fluctuations in the glucagon stimulation test. Growth Horm IGF Res 2009;19:77-81.
45 Goodwin PM, Capildeo R, Harrop JS, Marks V, Rose FC: The metabolic and hormonal response to glucagon. Part 1. Normal subjects. J Neurol Sci 1976;27:373-380.

46 Tanaka T, Suwa S: The effect of alpha adrenergic receptor blockade on the glucagon-induced growth hormone response. Clin Endocrinol (Oxf) 1978;9:267-272.

47 Maghnie M, Valtorta A, Moretta A, Larizza D, Preti P, Palladini G, Calcante S, Severi F: Diagnosing growth hormone deficiency: the value of short-term hypocaloric diet. J Clin Endocrinol Metab 1993;77:1372-1378.

48 Ho KY, Veldhuis JD, Johnson ML, Furlanetto R, Evans WS, Alberti KG, Thorner MO: Fasting enhances growth hormone secretion and amplifies the complex rhythms of growth hormone secretion in man. J Clin Invest 1988; 81:968-975.

49 Cain JP, Williams GH, Dluhy RG: Glucagon stimulation of human growth hormone. J Clin Endocrinol Metab 1970;31:222-224.
50 Hawkes CP, Mavinkurve M, Fallon M, Grimberg A, Cody DC: Serial GH measurement after intravenous catheter placement alone can detect levels above stimulation test thresholds in children. J Clin Endocrinol Metab 2015; 100:4357-4363.

51 Eddy RL, Jones AL, Hirsch RM: Effect of exogenous glucagon on pituitary polypeptide hormone release. Metabolism 1970;19:904912.

52 Ghigo E, Bartolotta E, Imperiale E, Bellone J, Cardinale G, Aimaretti G, Valetto MR, Cherubini V, Maccario M, Cocchi D, et al: Glucagon stimulates GH secretion after intramuscular but not intravenous administration. Evidence against the assumption that glucagon per se has a GH-releasing activity. J Endocrinol Invest 1994;17:849-854. 